\title{
The Sustainable Development System Structural Model of Shaanxi Coal Industry
}

\author{
Li Guo (Corresponding author) \\ Energy Economy and Management Research Center, Xi'an University of Science and Technology \\ Xi'an 710054, China
}

Tel: 86-139-0925-0069 E-mail: christie_guo@163.com

Received: November 15, $2011 \quad$ Accepted: December 5, $2011 \quad$ Published: January 1, 2012

doi:10.5539/jsd.v5n1p128

URL: http://dx.doi.org/10.5539/jsd.v5n1p128

This paper is funded by the National Soft Science Program (2006GXQ3D160), the Key Project of Shaanxi Soft Science Research Program (2010KRZ02), the Science Research Program of Shaanxi Education Department (11JK0057), and the Science and Research Cultivation Foundation of Xi'an University of Science \& Technology (2010014).

\begin{abstract}
In this paper, the author uses the Interpretative Structural Modeling Method (ISM) to analyze the factors of sustainable development system of Shaanxi coal industry. Take the environmental capacity, economic development, social development, and resources capacity as the first-grade indicator system, and environmental protection measures, clean coal technology, coal utilization, clean mining technology, management innovation, technology innovation, and coal resource management as the second-grade indicator system. Build a reach ability matrix to reflect the relationships of all factors in the system and form a structural model for the sustainable development system of Shaanxi coal industry.
\end{abstract}

Keywords: Coal, Sustainable development, System structure, Mode

\section{Introduction}

Coal is a consumable and non-renewable resource and one of most abundant and effective fossil energies in the world. China is a giant country with rich coal resources, more coal production and consumption. The position of coal in China's energy structure would be lasted and stable. Shaanxi is one of coal-rich areas in China. Among the 13 large national coal bases, Shaanxi, as the important coal industrial base, has three of them, namely Shendong, Shaanbei, and Huanglong. Shaanxi's coal industry has a more important position in the development of China's coal industry.

Currently in Shaanxi province, the coal industry has entered the fast-development stage. However, with its fast development, some discontent problems appear. In Shaanxi, coals are seldom transformed or deeply processed locally. Most raw coals with low added values are exported directly. In collieries of Shaanxi, more than $60 \%$ of front production workers only have primary-school education. There are only 60 people or so with technical secondary school education. Most mines have no technicians and the full-time safety staff is not quite qualified. Most of small mines depend on digging instead of mining, without appropriate support and protection equipments. The recovery ratio is less than $30 \%$, far less than the national standard. In Shaanxi province, areas with collieries have fragile ecology. Coal mining triggers more and more geological disasters, such as landslides, surface subsidence, and exhaustion of water resources, causing losses and damages for people's life and properties. These problems seriously affect the sustainable development of Shaanxi coal industry. The purpose of building the sustainable development system structural model of Shaanxi coal industry is to express the interdependent relationships of different factors scientifically, building the basis for the establishment of a complete system.

The sustainable development of coal industry is a new mode of structural reform of coal industry, which means that the development of coal industry should meet the needs for economic development while preserving the human needs for environment and ecology, and meet the needs of present generation while not harming the ability of future generations meeting their needs. The consumption of coal resources should stay in an appropriate level so that human beings have enough time to turn to alternative resources when coals become 
extremely expensive and scarce. In specific meanings, the sustainable development of coal industry includes four aspects: sustainable development of economy, sustainable development of society, sustainable resources, and sustainable environment (Xinchun Li, 2000). After years of researches, starting from the non-renewable nature of coal resources and from the perspective of system, Tong Wei defines the sustainable development of coal industry as: the economic development, social development, environmental protection, resource development and utilization are in mutual coordination in areas with coal industry, and the coal industry can provide clean fuels, raw materials, and powers for the society (Tong Wei, 1997). Dequn Zhou points out that: the sustainable development of coal industry aims at properly using the law, policy and market mechanism, depending on scientific and technological progresses, exploring, processing, and utilizing coal resources reasonably and scientifically as much as possible, improving the economic effects and ecological benefits of coal enterprises, and ensuring the sustainable development of society, economy, and ecological environment (Dequn Zhou, 2001). Guohao Zhao thinks that the sustainable development of coal industry means the coordination of economic development, social progress, scientific and technological progress, development and utilization of resources, and environmental protection, and the coal industry should provide clean fuels, raw materials, and powers for the society, achieving the maximum benefits of society, economy, and environment (Guohao Zhao, 2008).

These researches deepen the system of sustainable development and have certain significance for the study of the sustainable development of coal industry. However, coal resources are local. Different areas have to follow specific thoughts, points, and requirements for the sustainable development of coal industry. Therefore, it is necessary to develop the theory of sustainable development of coal industry in local areas.

\section{Method and Model}

Use the Interpretative Structural Modeling Method (ISM) to build the sustainable development system structural model of Shaanxi coal industry (Yingluo Wang, 2002). In details:

First, select the system factors and establish the basis for the system structural model.

Second, establish the adjacency matrix A. The adjacency matrix is used to describe the relationship of each node (namely the factor). Define the factor of adjacent matrix A as follow:

$$
\mathrm{Sij}=\left\{\begin{array}{ccc}
1 & \mathrm{Si} \text { has certain relationship with } \mathrm{Sj} \\
& 0 & \mathrm{Si} \text { has no relationship with } \mathrm{Sj}
\end{array}\right.
$$

The reach ability matrix can be used to analyze the relationship of factors in the system because of its nature of reach ability. As the system factor $\mathrm{Si}$ can reach $\mathrm{Sn}$, and $\mathrm{Sn}$ can reach $\mathrm{Sj}$, then $\mathrm{Si}$ will inevitably reach $\mathrm{Sj}$.

Third, according to the reach ability matrix, establish the interpretative structural modeling diagrams. Introduce relevant factors into the right positions and get the interpretative structural model.

\section{The Factor Analysis of the Sustainable Development System of Shaanxi Coal Industry}

The selection of system factors is the basis for establishing the sustainable development system structural model of Shaanxi coal industry. According to the characteristics of Shaanxi coal industry and the connotations of sustainable development, select the system factors as follow (Table 1):

\section{Establish the Sustainable Development System Structural Model of Shaanxi Coal Industry}

In this paper, the author uses the Interpretative Structural Modeling Method (ISM) to build the sustainable development system structural model of Shaanxi coal industry. In detail, the specific steps include:

\subsection{Establish the Adjacent Matrix}

The adjacent matrix $\mathrm{A}=\left[\mathrm{S}_{\mathrm{ij}}\right]_{16 \times 16}$ in Table 2.

\subsection{Establish the Reach Ability Matrix}

The reach ability matrix can be used to analyze the relationship of factors in the system because of its nature of reach ability. As the system factor $S_{i}$ can reach $S_{n}$, and $S_{n}$ can reach $S_{j}$, then $S_{i}$ will inevitably reach $S_{j}$.

The reach ability matrix is in Table 3 .

\subsection{Establish the Hierarchical Structure Model}

According to the reach ability matrix, establish the interpretative structural modeling diagrams. Introduce relevant system factors into the right positions and get the interpretative structural model. See Figure 1.

\section{Conclusion}

Studies show that the sustainable development system of Shaanxi coal industry has three levels. The first level 
includes four factors: the environmental capacity, that is how much the ecology can bear the coal mining, the economic development, that is the economic basis for achieving the system objective, the social development, that is the social basis for achieving the system objective, the resource capacity, that is whether coal resources meet the needs of present generation while not harming the needs of future generations. The second level includes management innovation, technical innovation, comprehensive utilization coals, clean coal technology, clean mining technology, environmental protection measures, and coal resource management. The third level is mainly the government's organization, execution, and participation.

The model shows that, firstly, management innovation and technical innovation have direct impacts on all factors at the first level. Therefore, in order to realize the sustainable development of Shaanxi coal industry, we must emphasize on management and technical innovation. Secondly, environmental protection measures and clean coal technology have direct impacts on environmental capacity. Therefore, in order to improve and enhance the capacity of ecology bearing coal mining, we should strictly ask coal production enterprises to adopt the clean coal production technology, in addition to relevant environmental protection measures. Thirdly, as for economic development, only by increasing the comprehensive utilization of coals, extending the industrial chain, improving the added value of coals, adopting the clean mining technology, and depending on clean coal technology, can we guarantee the sustainable development of economy. Fourthly, the resource capacity depends more on coal resource management and clean mining technology. Therefore, the government should develop reasonable coal mining program and resource taxes, strengthen the effective management of coal resources, and achieve the sustainable development of resources.

\section{Reference}

The World Commission on Environment and Development. (1987). Our Common Future. America: Oxford University Press.

Xinchun Li \& Xueyu Tao. (2000). Application of neural network with multi hierarchic structure to evaluate sustainable development of the coal mines. Journal of Coal Science \& Engineering. 6, 33-34.

Tong Wei. (1997). A systematic analysis of sustainable development of China Coal Industry. China Coal. 23, 15-20.

Dequn Zhou. (2001). Sustainable development of energy industry: concept, indicator system and measurement. Journal of China Coal Society. 5, 449-454.

Guohao Zhao. (2008). Systematic Analysis of Sustainable Development of Coal Industry (pp. 80-83). Beijing: Economy \& Management Publishing House.

Yingluo Wang. (2002). Systems Engineering Theories, Methods, and Applications (pp. 33-50). Beijing: High Education Press. 
Table 1 . The factor analysis of sustainable development of Shaanxi coal industry

\begin{tabular}{|c|c|c|}
\hline System factor & Sign & Main contents \\
\hline Sustainable development & $\mathrm{S}_{1}$ & $\begin{array}{c}\text { Ultimate objective of the sustainable development system of } \\
\text { Shaanxi coal industry }\end{array}$ \\
\hline Economic development & $\mathrm{S}_{2}$ & Economic basis for achieving the system objective \\
\hline Social development & $\mathrm{S}_{3}$ & Social basis for achieving the system objective \\
\hline Environmental capacity & $\mathrm{S}_{4}$ & Ecological capacity of coal mining \\
\hline Resources capacity & $\mathrm{S}_{5}$ & $\begin{array}{l}\text { Whether coal resources can meet the needs of present } \\
\text { generation while not harming the needs of future generations }\end{array}$ \\
\hline $\begin{array}{l}\text { Comprehensive utilization of } \\
\text { coals }\end{array}$ & $\mathrm{S}_{6}$ & Comprehensive exploration and utilization of coals \\
\hline Clean coal technology & $\mathrm{S}_{7}$ & $\begin{array}{l}\text { Processing and transforming technologies that improve the } \\
\text { efficiency of coal utilization }\end{array}$ \\
\hline Clean mining technology & $\mathrm{S}_{8}$ & $\begin{array}{c}\text { Technology that reduce environmental pollution in the } \\
\text { process of coal mining }\end{array}$ \\
\hline $\begin{array}{c}\text { Environmental protection } \\
\text { measure }\end{array}$ & $\mathrm{S}_{9}$ & $\begin{array}{c}\begin{array}{c}\text { Environmental protection measures established by the } \\
\text { government }\end{array} \\
\text {. }\end{array}$ \\
\hline Coal resouce management & $\mathrm{S}_{10}$ & Resource protection and resource guaranty \\
\hline $\begin{array}{l}\text { Execution and participation } \\
\text { of government }\end{array}$ & $\mathrm{S}_{11}$ & $\begin{array}{c}\text { Organize, manage, and monitor the application and advocate } \\
\text { the social participation }\end{array}$ \\
\hline Knowledge economy & $\mathrm{S}_{12}$ & $\begin{array}{l}\text { Education helps the public to understand the necessity of } \\
\text { sustainable development and build a consciousness of } \\
\text { participation }\end{array}$ \\
\hline Policies and laws & $\mathrm{S}_{13}$ & Constitute laws and regulations and provide policy guaranty \\
\hline $\begin{array}{l}\text { Industrial structure } \\
\text { adjustment }\end{array}$ & $\mathrm{S}_{14}$ & Industrial program, organization, and coordination \\
\hline Technical innovation & $\mathrm{S}_{15}$ & Aim at technical reform and popularization \\
\hline Institutional innovation & $\mathrm{S}_{16}$ & Aim at institutional reform and building \\
\hline
\end{tabular}

Table 2. The adacent matrix of system factors

\begin{tabular}{ccccccccccccccccc}
\hline & $\mathrm{S}_{1}$ & $\mathrm{~S}_{2}$ & $\mathrm{~S}_{3}$ & $\mathrm{~S}_{4}$ & $\mathrm{~S}_{5}$ & $\mathrm{~S}_{6}$ & $\mathrm{~S}_{7}$ & $\mathrm{~S}_{8}$ & $\mathrm{~S}_{9}$ & $\mathrm{~S}_{10}$ & $\mathrm{~S}_{11}$ & $\mathrm{~S}_{12}$ & $\mathrm{~S}_{13}$ & $\mathrm{~S}_{14}$ & $\mathrm{~S}_{15}$ & $\mathrm{~S}_{16}$ \\
\hline $\mathrm{S}_{1}$ & 1 & 0 & 0 & 0 & 0 & 0 & 0 & 0 & 0 & 0 & 0 & 0 & 0 & 0 & 0 & 0 \\
$\mathrm{~S}_{2}$ & 1 & 1 & 0 & 0 & 0 & 0 & 0 & 0 & 0 & 0 & 0 & 0 & 0 & 0 & 0 & 0 \\
$\mathrm{~S}_{3}$ & 1 & 0 & 1 & 0 & 0 & 0 & 0 & 0 & 0 & 0 & 0 & 0 & 0 & 0 & 0 & 0 \\
$\mathrm{~S}_{4}$ & 1 & 0 & 0 & 1 & 0 & 0 & 0 & 0 & 0 & 0 & 0 & 0 & 0 & 0 & 0 & 0 \\
$\mathrm{~S}_{5}$ & 1 & 0 & 0 & 0 & 1 & 0 & 0 & 0 & 0 & 0 & 0 & 0 & 0 & 0 & 0 & 0 \\
$\mathrm{~S}_{6}$ & 1 & 1 & 0 & 0 & 0 & 1 & 0 & 0 & 0 & 0 & 0 & 0 & 0 & 0 & 0 & 0 \\
$\mathrm{~S}_{7}$ & 1 & 1 & 0 & 1 & 0 & 0 & 1 & 0 & 0 & 0 & 0 & 0 & 0 & 0 & 0 & 0 \\
$\mathrm{~S}_{8}$ & 1 & 1 & 0 & 1 & 0 & 0 & 0 & 1 & 0 & 0 & 0 & 0 & 0 & 0 & 0 & 0 \\
$\mathrm{~S}_{9}$ & 1 & 0 & 0 & 1 & 0 & 0 & 0 & 0 & 1 & 0 & 0 & 0 & 0 & 0 & 0 & 0 \\
$\mathrm{~S}_{10}$ & 1 & 0 & 0 & 0 & 1 & 0 & 0 & 0 & 0 & 1 & 0 & 0 & 0 & 0 & 0 & 0 \\
$\mathrm{~S}_{11}$ & 1 & 1 & 1 & 1 & 1 & 1 & 1 & 1 & 1 & 1 & 1 & 1 & 1 & 0 & 0 & 0 \\
$\mathrm{~S}_{12}$ & 1 & 1 & 1 & 1 & 1 & 1 & 1 & 1 & 1 & 1 & 1 & 1 & 0 & 0 & 0 & 0 \\
$\mathrm{~S}_{13}$ & 1 & 1 & 1 & 1 & 1 & 1 & 1 & 1 & 1 & 1 & 1 & 1 & 1 & 1 & 0 & 0 \\
$\mathrm{~S}_{14}$ & 1 & 1 & 1 & 1 & 1 & 1 & 1 & 1 & 1 & 1 & 1 & 1 & 1 & 1 & 0 & 0 \\
$\mathrm{~S}_{15}$ & 1 & 1 & 1 & 1 & 1 & 0 & 0 & 0 & 0 & 0 & 0 & 0 & 0 & 0 & 1 & 0 \\
$\mathrm{~S}_{16}$ & 1 & 1 & 1 & 1 & 1 & 0 & 0 & 0 & 0 & 0 & 0 & 0 & 0 & 0 & 0 & 1 \\
\hline
\end{tabular}


Table 3. The reach ability matrix of system factors

\begin{tabular}{ccccccccccccccccc}
\hline & $\mathrm{S}_{1}$ & $\mathrm{~S}_{2}$ & $\mathrm{~S}_{3}$ & $\mathrm{~S}_{4}$ & $\mathrm{~S}_{5}$ & $\mathrm{~S}_{6}$ & $\mathrm{~S}_{7}$ & $\mathrm{~S}_{8}$ & $\mathrm{~S}_{9}$ & $\mathrm{~S}_{10}$ & $\mathrm{~S}_{11}$ & $\mathrm{~S}_{12}$ & $\mathrm{~S}_{13}$ & $\mathrm{~S}_{14}$ & $\mathrm{~S}_{15}$ & $\mathrm{~S}_{16}$ \\
\hline $\mathrm{S}_{1}$ & 1 & 0 & 0 & 0 & 0 & 0 & 0 & 0 & 0 & 0 & 0 & 0 & 0 & 0 & 0 & 0 \\
$\mathrm{~S}_{2}$ & 1 & 1 & 0 & 0 & 0 & 0 & 0 & 0 & 0 & 0 & 0 & 0 & 0 & 0 & 0 & 0 \\
$\mathrm{~S}_{3}$ & 1 & 0 & 1 & 0 & 0 & 0 & 0 & 0 & 0 & 0 & 0 & 0 & 0 & 0 & 0 & 0 \\
$\mathrm{~S}_{4}$ & 1 & 0 & 0 & 1 & 0 & 0 & 0 & 0 & 0 & 0 & 0 & 0 & 0 & 0 & 0 & 0 \\
$\mathrm{~S}_{5}$ & 1 & 0 & 0 & 0 & 1 & 0 & 0 & 0 & 0 & 0 & 0 & 0 & 0 & 0 & 0 & 0 \\
$\mathrm{~S}_{6}$ & 1 & 1 & 0 & 0 & 0 & 0 & 0 & 0 & 0 & 0 & 0 & 0 & 0 & 0 & 0 & 0 \\
$\mathrm{~S}_{7}$ & 1 & 1 & 0 & 1 & 0 & 0 & 1 & 0 & 0 & 0 & 0 & 0 & 0 & 0 & 0 & 0 \\
$\mathrm{~S}_{8}$ & 1 & 1 & 0 & 1 & 0 & 0 & 0 & 1 & 0 & 0 & 0 & 0 & 0 & 0 & 0 & 0 \\
$\mathrm{~S}_{9}$ & 1 & 0 & 0 & 1 & 0 & 0 & 0 & 0 & 1 & 0 & 0 & 0 & 0 & 0 & 0 & 0 \\
$\mathrm{~S}_{10}$ & 1 & 1 & 1 & 1 & 1 & 1 & 1 & 1 & 1 & 1 & 0 & 0 & 0 & 0 & 0 & 0 \\
$\mathrm{~S}_{11}$ & 1 & 1 & 1 & 1 & 1 & 1 & 1 & 1 & 1 & 1 & 1 & 1 & 1 & 1 & 0 & 0 \\
$\mathrm{~S}_{12}$ & 1 & 1 & 1 & 1 & 1 & 1 & 1 & 1 & 1 & 1 & 1 & 1 & 1 & 1 & 0 & 0 \\
$\mathrm{~S}_{13}$ & 1 & 1 & 1 & 1 & 1 & 1 & 1 & 1 & 1 & 1 & 1 & 1 & 1 & 1 & 0 & 0 \\
$\mathrm{~S}_{14}$ & 1 & 1 & 1 & 1 & 1 & 1 & 1 & 1 & 1 & 1 & 1 & 1 & 1 & 1 & 0 & 0 \\
$\mathrm{~S}_{15}$ & 1 & 1 & 1 & 1 & 1 & 0 & 0 & 0 & 0 & 0 & 0 & 0 & 0 & 0 & 1 & 0 \\
$\mathrm{~S}_{16}$ & 1 & 1 & 1 & 1 & 1 & 0 & 0 & 0 & 0 & 0 & 0 & 0 & 0 & 0 & 0 & 1 \\
\hline
\end{tabular}

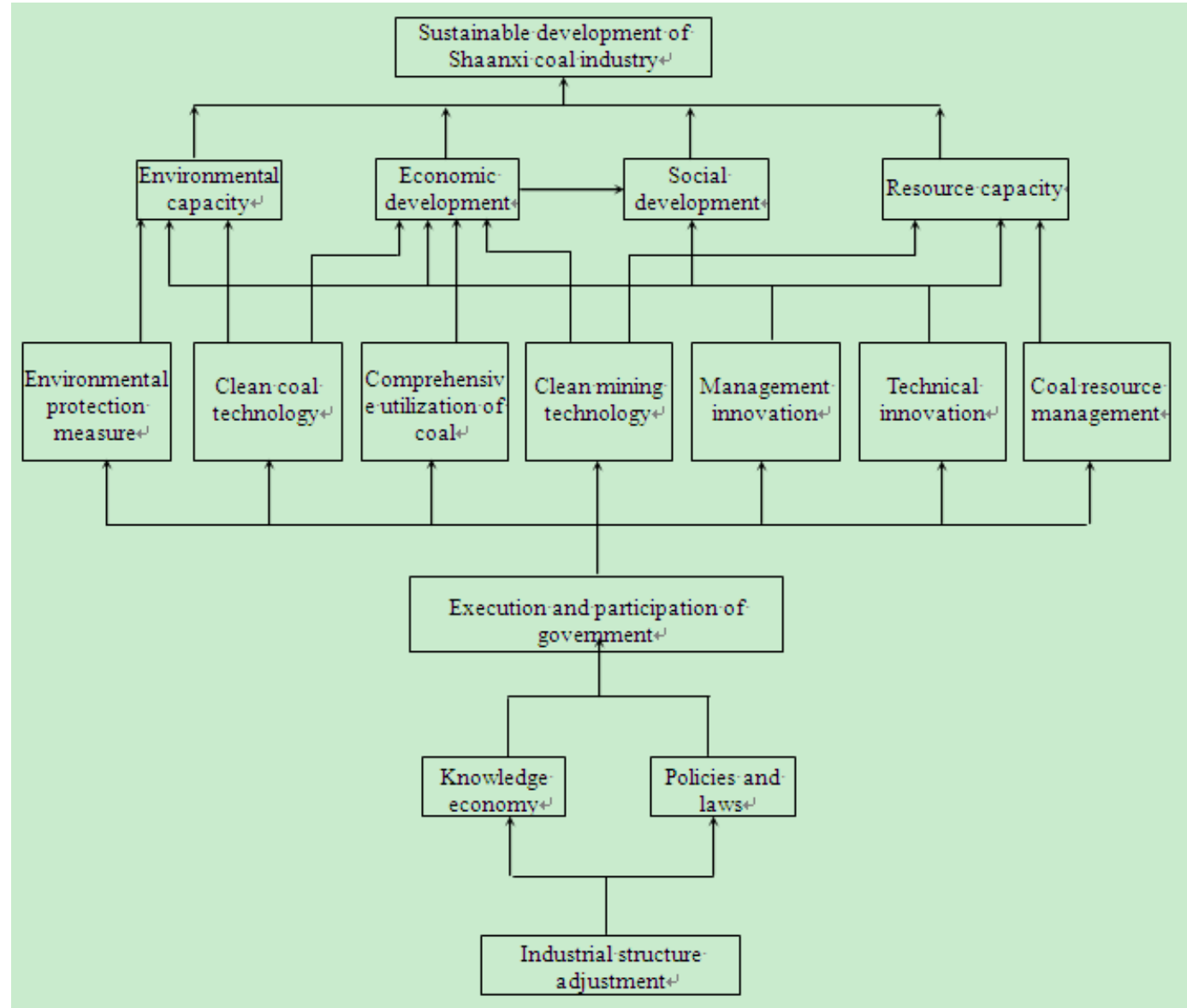

Figure 1. The sustainable development system structural model of Shaanxi coal industry 